\title{
PEMODELAN HYBRID SINTESIS PADA AUTOMATED MANUFACTURING SYSTEM (AMS) DENGAN MENGGUNAKAN PETRI NET
}

\author{
DORTEUS LODEWYIK RAHAKBAUW \\ Staf Jurusan Matematika FMIPA UNPATTI \\ J1. Ir. M. Putuhena, Kampus Unpatti, Poka-Ambon \\ e-mail: lodewyik@gmail.com
}

\begin{abstract}
ABSTRAK
Dalam Jurnal ini dibahas masalah sistem even diskrit yang ada pada Automated Manufacturing System (AMS), khususnya menyangkut model, kedinamikan, dan mendesain sistem AMS dengan menggunakan tool matematik Petri net. Selanjutnya dikonstruksikan suatu model AMS yang komponen utamanya terdiri dari dua entry, dua exit, lima mesin, dua buffer, empat robot, dan dua sistem Automated Guided Vehicle (AGV) yang ada dalam AMS, dimana masing-masing komponen tersebut memiliki deskripsi kerja berlainan sesuai tugas masing-masing. Dengan menggunakan metode hybrid, AMS akan ditransformasikan ke dalam tool matematik Petri net dengan menggunakan deskripsi sintesis yang didalamnya terdiri atas dua prosedur kerja yaitu top-down design dan bottomup design. Dekomposisi (decomposition) dan penghalusan (refinement) yang meliputi penambahan place shared dan non-shared resource ke dalam Petri net dibutuhkan untuk mendapatkan desain Petri net AMS yang akan mengurangi atau menghilangkan deadlock pada sistem AMS. Dengan demikian, suatu definisi dari hybrid sintesis serta struktur Petri net dapat terjawab. Perilaku mendesain sistem ini akan dibahas untuk mendapatkan suatu desain yang efektif dalam fungsi dan penggunaan AMS tersebut.
\end{abstract}

Keywords: AMS, Hybrid sintesis, Petri net, Coverability tree.

\section{PENDAHULUAN}

Dalam perkembangan Petri net (Murata, 1989) adalah suatu pemodelan formal yang diperkenalkan oleh Carl Adam Petri pada tahun 1962 untuk memodelkan sistem terdistribusi. Petri net cepat berkembang sebagai suatu hal yang menjanjikan dalam pemodelan, sehubungan dengan fungsinya untuk mewakili sejumlah fitur dari perilaku sistem dinamik event diskrit. Sistem event-driven meliputi manufaktur otomatis, jaringan komunikasi, sistem operasi komputer, sistem informasi kantor, dan lainnya. Mungkin tidak bersamaan dan bertahap namun memperlihatkan beberapa karakteristik, diantaranya: concurrency, conflict, mutual exclusion, dan non-determinism. Karakteristikkarakteristik ini cukup sulit jika dideskripsikan menggunakan teori kontrol tradisional yang merujuk pada sistem kontinu atau model variabel-variabel diskrit bersamaan dengan persamaan beda atau diferensial. Sebagai tambahan, kontrol tidak sesuai dengan kejadian dari suatu peristiwa yang mungkin sebagai pemicu menuju sistem deadlock, kapasitas berlebihan, atau menurunkan tingkatan kinerja sistem. Tipe dari sistem ini disebut Discrete Event Systems (DES) atau sering juga disebut Discrete Event Dynamic Systems (DEDS).

Dalam penelitian ini akan dikaji permasalahan sistem manufaktur yang dikonstruksi, dan dengan menggunakan hybrid sintesis Petri net untuk mendapatkan perilaku serta karakteristik sistem yang diharapkan mampu menghindari deadlock dalam sistem tersebut. Digunakan juga tool Petri net Platform Independent Petri net Editor (PIPE) karena menggunakan representasi grafik sehingga Pembuatan Petri net lebih mudah.

\section{TINJAUAN PUSTAKA}

\section{PETRI NET DAN SISTEM MANUFAKTUR}

Petri net diperkenalkan oleh Carl A. Petri pada tahun 1962. Sejak saat itu berkembang sebagai suatu tool untuk memodelkan, menganalisis dan sebagai kontrol suatu sistem event diskrit. 
Definisi 1. (Zhou dan DiCesare, 1993) Petri net. Petri net ditulis $Z=\left(P, T, I, O, m_{0}\right)$ dimana,

- $P$ : himpunan place-place, secara grafik digambarkan sebagai bulatan;

- $T$ : himpunan transisi-transisi, secara grafik digambarkan sebagai batangan, dengan $P \cup T \neq 0$ dan $P \cap T=0$;

- $\quad I: P \times T \rightarrow\{0,1\}$ adalah fungsi input secara spesifik arc yang diarahkan dari place ke transisi;

- $O: P \times T \rightarrow\{0,1\}$ adalah fungsi output secara spesifik arc yang diarahkan dari transisi ke place;

- $m: P \rightarrow T$ adalah penandaan sebanyak $i$ komponen yaitu jumlah token, secara grafik digambarkan sebagai titik, dalam place ke-i. $m_{0}$ adalah inisialisasi penandaan dimana $N=\{0,1,2, \ldots\}$.

Petri net memiliki arah, bobot, dan merupakan graph bipartite dengan dua bentuk node yaitu place dan transisi. arc (Panah) terkoneksi antara place dan transisi atau transisi dan place dan tidak akan bisa terkoneksi antar place atau antar transisi.

Pada bagian place berisi sejumlah token yang merupakan bilangan integer positif. Distribusi token pada petri net disebut penandaan (marking). Ketika perilaku dari suatu sistem dimodelkan dalam bentuk Petri net, penandaan diindikasikan sebagai state dalam suatu sistem.

Manufaktur merupakan himpunan aktivitas yang berinteraksi dengan himpunan resource dan hasil dalam produksi. Aktivitas yang dimaksudkan adalah proses manufaktur yang melibatkan pengerjaan dengan mesin, penanganan bahan, dan informasi pemrosesan yang harus terjadi untuk memproduksi sesuatu. Resourcenya merupakan personalia, mesin, bahan baku dan seterusnya yang memerlukan pelaksanaan aktivitas ini. Perencanaan proses produksi memerlukan aktivitas dan resource yang sangat detail. Ini meliputi prioritas yang lebih tinggi antara aktivitas, dalam artian beberapa aktivitas harus terjadi sebelum yang lain. Proses perencanaan mungkin menetapkan beberapa resource untuk aktivitas dan memberikan beberapa prioritas ke mana resource akan memilihnya.

Petri net terdefinisi dalam bentuk grafik dan matematik serta tidak memiliki arti fisik. Dalam penerapannya dibutuhkan interpretasi dengan pelabelan terhadap place dan transisi. Secara umum dalam pemodelan Petri net, place (bulat) menyatakan kondisi dan transisi (bar) menyatakan event. Dalam penelitian ini untuk memodelkan sistem manufaktur dengan menggunakan Petri net, interpretasi untuk place, transisi, dan token adalah sebagai berikut:

a. Place merepresentasikan status resource atau operasi, saat mewakili bentuk pertama, jumlah inisial token adalah konstan, misalnya jumlah mesin mengasumsikan bahwa plantnya adalah tetap, atau variabel, misalnya jumlah job atau palet pada sistem.

b. Jika place merepresentasikan status resource, satu atau lebih token pada place mengartikan bahwa resource tersedia, dan jika tidak ada token mengartikan tidak tersedia. Jika place merepresentasikan operasi, maka token didalamnya menunjukkan operasi dilakukan dan jika tidak ada token mengartikan operasi tidak sedang dilakukan.

c. Transisi merepresentasikan mulai atau selesainya suatu event atau penyelesaian suatu proses operasi.

\section{MODEL KONSTRUKSI}

\section{AUTOMATED MANUFACTURING SYSTEM}

Terdapat automated manufacturing system(AGV) yang terdiri atas komponen utama sebagai berikut: dua entri, dua exit, lima mesin, dua buffer, empat robot, dan dua sistem AGV seperti dalam Gambar 1. Berikutnya dijelaskan deskripsi masing-masing komponen utama AGV sebagai berikut:

Entri : Terdapat dua entri untuk dua tipe bahan baku, $F$ dan $G$, yang memproduksi dua bentuk produksi berbeda. Setiap potongan bahan baku sudah di patenkan sehingga dapat dikirim menggunakan robot dan dua sistem AGV.

Exit: Terdapat dua exit untuk pengiriman akhir bagian $F$ dan bagian $G$ berturut-turut. Proses output dapat diselesaikan via dua sistem AGV.

Mesin: Mesin $M_{1}$ dan $M_{2}$ memproses potongan bahan $F$ dari entri 1 . Kedua mesin memproduksi bagian $F$ yang nantinya akan dikirim ke buffer 1 . Bagian perantara ini selanjutnya diproses oleh $M_{3}$ untuk memproduksi bagian akhir dari bahan $F$. Mesin $M_{4}$ memproses potongan bahan dari entri 2 dan memproduksikan bagian-bagian $G$ yang akan dikirim ke buffer 2. Mesin $M_{5}$ merupakan perantara dari bahan $G$ dari buffer 2 .

Buffer: buffer 1 pada ukuran $b_{1}$ mendapatkan bagian $F$ dari $M_{1}$ atau $M_{2}$. Output ini adalah perantara bagianbagian $F$ satu per satu ke $M_{3}$. buffer 2 pada ukuran $b_{2}$ mendapatkan proses bagian $G$ dari $M_{4}$. Output ini merupakan bagian-bagian $G$ satu per satu ke $M_{5}$.

Robot: Robot $R_{1}$ mengisi $M_{1}, M_{2}$ dan $M_{3}$, dan tidak dari ketiga mesin merupakan prioritas untuk dilayani robot tersebut. Dalam aturan non-deterministik, $R_{l}$ memilih mesin jika bahan baku sudah tersedia dan mesin sudah siap. Robot $R_{2}$ membongkar $M_{3}$ dan $M_{5}$, serta mengirim bagian-bagian yang sudah selesai/lengkap ke palet yang ada pada sistem AGV. Robot $R_{3}$ berbagi dengan $M_{1}, M_{2}$ dan $M_{3}$. Berikut fungsi yang dilaksanakan : membongkar $M_{1}$, dan $M_{2}$ sampai bagian perantara tipe $F$ ke dan dari buffer 1, dan mengisi $M_{3}$. Setiap pemrosesan bagian $F$ 
dengan $M_{1}$ atau $M_{2}$ harus disimpan dalam buffer 1 sebelum proses selanjutnya.

Desain seperti ini mencegah pemrosesan yang baru berjalan oleh $M_{1}$ atau $M_{2}$ dari proses perantara oleh $M_{3}$. Sama halnya, robot $R_{4}$ digunakan untuk melayani $M_{4}$ dan $M_{5}$. Ini bisa digunakan untuk membongkar $M_{4}$ untuk mengirim bagian perantara tipe $F$ ke dan dari buffer 2 , dan mengisi $M_{5}$. Buffer 2 menjalankan fungsi yang sama seperti yang dilakukan buffer 1. Sistem AGV: Dua AGV didesain untuk pengiriman bahan final dan menjalankan palet dalam sistem.

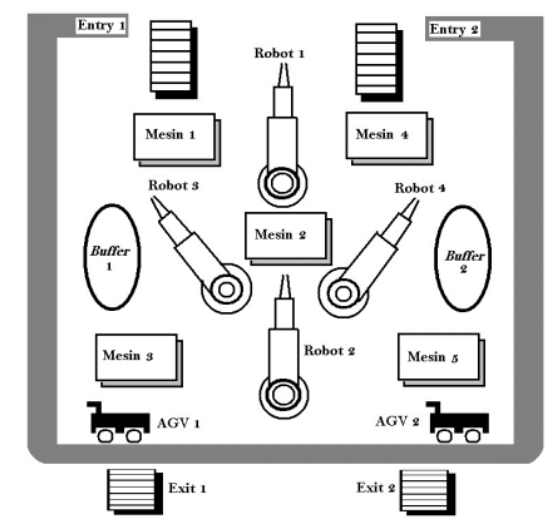

Gambar 1. Stasiun Transfer Bahan baku

Dari $M_{3}$, AGV 1 mengirim bagian final $F$ ke output dan palet kembali ke entri 1 dari $M_{5}$, AGV 2 mengirim bahan final $G$ ke output dan palet kembali ke entri 2. Saat bagian berbeda diambil deadlock dapat dihindari. Baik keduanya, AGV dapat bekerja bersamaan setelah robot 2 meletakkan bagian pada palet satu per satu.

\section{METODE SINTESIS}

Metode sintesis terdiri dari dua bagian utama, yang masing-masing memiliki bagian penting dalam mendesain sistem. Metode sintesis terbagi menjadi desain top-down dan desain bottom-up. Berikut deskripsi dari metode sintesis.

Desain Top-down: Langkah 1: memilih Petri net yang reversible, live, dan bounded sebagai model first-level dari suatu sistem yang bekerja saat semua resource utama tersedia. dan menentukan $P_{A}, P_{B}$, dan $P_{C}$ dimana $P_{A}$ dan $P_{B}$ merupakan subjek untuk meningkatkan, sementara $P_{C}$ selalu tetap dan anggotanya memiliki jumlah variabel pada inisial token. Langkah 2: menguraikan sistem dalam beberapa subsistem di perlihatkan sebagai operasi place menggunakan modul desain dasar terdefinisi. Gantikan operasi place ini dengan modul desain dasar yang semakin detail sampai tidak ada operasi-operasi yang dapat dibagi selanjutnya atau sampai pada titik jangkau yang tidak diperlukan. $P_{A}$ semakin meningkat di setiap langkah. Langkah 3: secara wajar menambah place nonshared resource pada setiap langkah, saat satu dari beberapa operasi memerlukan resource. Arc terhubung ke place resource sehingga Akibat 1 terpenuhi. Pada setiap penambahan hanya $P_{B}$ yang ditingkatkan.

Desain Bottom-up: Langkah 4: menambahkan setap place buffer, yang dipasangkan dengan place- $A$ yang sudah ada untuk merepresentasikan buffer, bentuk modul buffer Petri net jika setiap buffer ada. Setiap penambahan place buffer dengan inisialisasi token yang mana jumlahannya mengartikan kapasitas pada buffer yang menjadi place-B. Langkah 5: menambahkan place shared resource yang merupakan bentuk Paralel Mutual Exclusion (PME) atau Generalized Paralel Mutual Exclusion (GPME). Place-place resource akan menjadi place-B. Langkah 6: menambahkan place shared resource yang merupakan bentuk Sequential Mutual Exclusion (SME) atau Generalized Sequential Mutual Exclusion (GSME) dan menghitung kapasitas token yang terjangkau antara PME atau GPME, $\alpha, \beta$, dan $\gamma$, serta menentukan jumlah inisial token dalam $p, \forall p \in P_{B}$.

\section{HASIL DAN PEMBAHASAN}

Pada bagian ini akan di bahas proses modeling Petri net dengan menggunakan deskripsi sintesis.

Desain Petri net level pertama: tanpa mempertimbangkan shared resource, robot, sistem ini dapat ditunjukkan dalam dua subsistem yang saling bergantung subsistem kiri dan subsistem kanan. Subsistem kiri memuat tiga mesin, buffer, dan AGV. Subsistem kanan memuat dua mesin yang terhubung, buffer dan AGV. Saat struktur choice-synchronization tidak dilibatkan dalam dua subsistem ini, Petri net level pertama didesain dengan model yang memiliki dua bagian Petri net seperti pada Gambar 2. Kedua net merupakan choice-free net. Secara inisial ditulis: $P_{A}=\left\{p_{01}, p_{02}\right\} ; P_{B}=\emptyset ; P_{C}=\left\{p_{10}, p_{20}\right\}$.
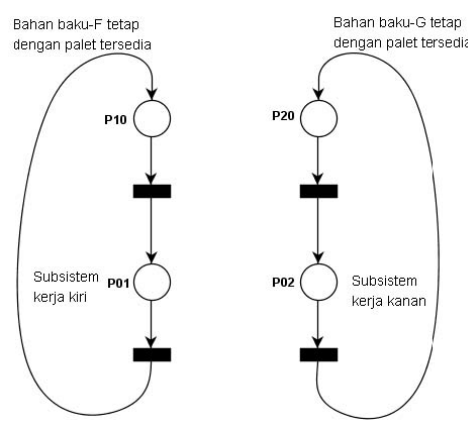

Gambar 2. Model Petri net level pertama memuat dua bagian net

Dekomposisi dan penghalusan operasi: untuk menjabarkan sistem ini secara lengkap, dekomposisi dan penghalusan sangat diperlukan. Kedua subsistem diuraikan menjadi tiga langkah untuk menggenerate produk akhir, baik $p_{01}$ dan $p_{02}$ pada model Petri net level pertama dalam Gambar 3 digantikan dengan tiga modul barisan place. Proses penghalusan net diperoleh sesuai Gambar 3 dimana,

$$
P_{A}=\left\{p_{01 a}, p_{1 b}, p_{01 c}, p_{02 a}, p_{2 b}, p_{02 c}\right\}
$$




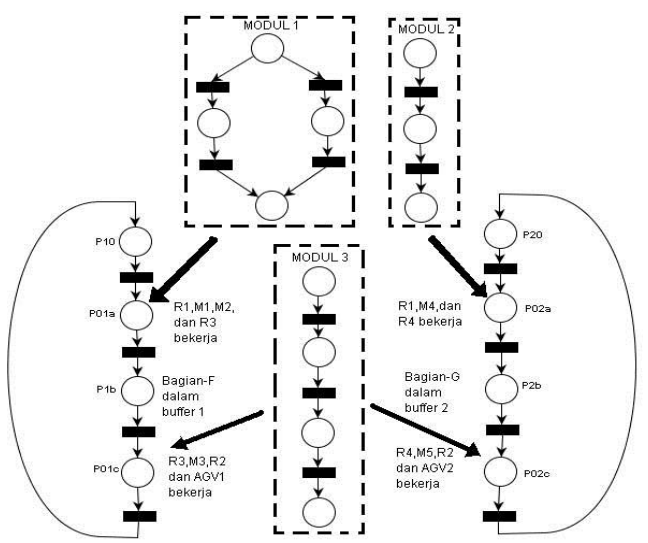

Gambar 3. Petri net setelah penghalusan pada place $p_{01}$ dan $p_{02}$

Arti masing-masing place dijelaskan pada Gambar. 4 dan Tabel. 1. Selanjutnya dekomposisi dan penghalusan dilakukan yaitu:

1. Place $p_{01 a}$ diganti dengan modul PN pilihan (modul 1 pada Gambar 3)

2. Place $p_{02 a}$ diganti dengan tiga barisan place modul PN (modul 2 pada Gambar 3)

3. Baik $p_{01 c}$ dan $p_{02 c}$ diganti dengan empat barisan place modul PN (modul 3 pada Gambar 3)

4. Place $p_{01 b}$ dan $p_{02 b}$ model perantara bagian $F$ dan $G$, masing-masing secara berurutan disimpan pada buffer 1 dan buffer 2. Setelah itu penghalusan untuk kedua place ini tidak dibutuhkan.
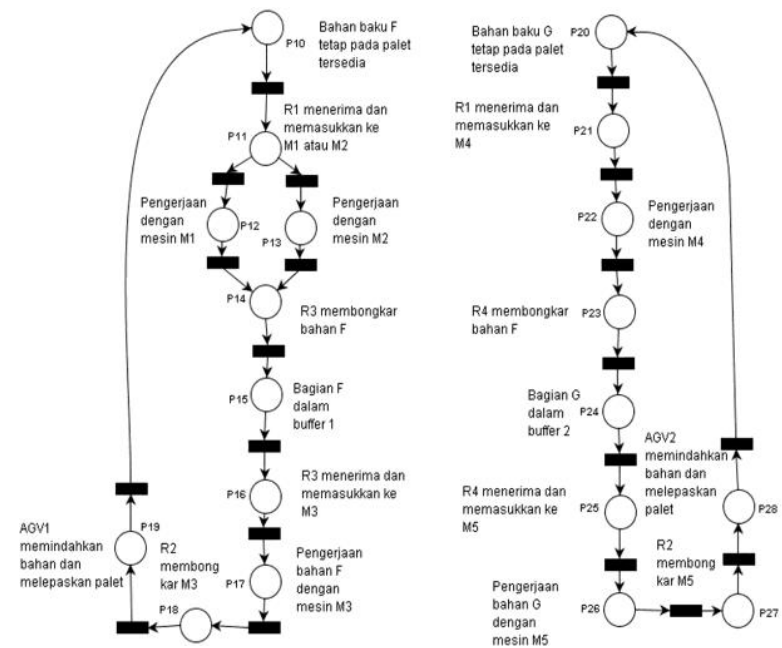

Gambar 4. Petri net setelah penghalusan pada $p_{01 a}, p_{02 a}, p_{01 c}$ dan $p_{02 c}$

Tabel 1. Label Place untuk Petri net pada Gambar 3.

\begin{tabular}{|c|l|}
\hline Place & \multicolumn{1}{|c|}{ Interpretasi } \\
\hline$p_{10}$ & $\begin{array}{l}\text { Bahan baku tipe } F \text { tersedia, Masing- } \\
\text { masing palet siap }\end{array}$ \\
\hline$p_{01 a}$ & $R_{1}, M_{1}, M_{2}$, dan $R_{3}$ bekerja \\
\hline$p_{1 b}$ & Bagian $F$ dalam buffer 1 \\
\hline$p_{01 c}$ & $R_{3}, M_{3}, R_{2}$, dan AGV1 bekerja \\
\hline$p_{20}$ & $\begin{array}{l}\text { Bahan baku tipe } G, \text { Masing-masing } \\
\text { tetap dengan palet tersedia }\end{array}$ \\
\hline$p_{02 a}$ & $R_{1}, M_{4}$, dan $R_{4}$ bekerja \\
\hline$p_{2 b}$ & Bagian $G$ dalam buffer 2 \\
\hline$p_{02 c}$ & $R_{4}, M_{5}, R_{2}$, dan AGV2 bekerja \\
\hline
\end{tabular}

Selanjutnya akan ditunjukkan penghalusan tersebut dengan melibatkan operasi place pada Gambar 5. Himpunan place operasi adalah, $P_{A}=p_{i j}, p_{19}, i=1,2$, dan $1 \leq j \leq 8$. Interpretasi place ini ditunjukkan pada Tabel 2.

Tabel 2. Label Place untuk Petri net pada Gambar 4.

\begin{tabular}{|c|c|}
\hline Place & Intepretasi \\
\hline$p_{10}$ & $\begin{array}{l}\text { Bahan baku tipe } F \text { tersedia, Masing- } \\
\text { masing palet siap }\end{array}$ \\
\hline$p_{11}$ & $\begin{array}{l}R_{l} \text { memperoleh palet dari entri } 1 \text { dan } \\
\text { mengisi } M_{1} \text { atau } M_{2}\end{array}$ \\
\hline$p_{12}$ & $\begin{array}{l}\text { Pengerjaan dengan mesin } M_{l} \text { bagian } \\
\text { bahan } F\end{array}$ \\
\hline$p_{13}$ & $\begin{array}{l}\text { Pengerjaan dengan mesin } M_{2} \text { bagian } \\
\text { bahan } F\end{array}$ \\
\hline$p_{14}$ & $\begin{array}{l}R_{3} \text { membongkar } M_{1} \text { atau } M_{2} \text { dan } \\
\text { menempatkan bagian F pada buffer } 1\end{array}$ \\
\hline$p_{15}$ & Buffer 1 menyimpan bagian $F$ \\
\hline$p_{16}$ & $\begin{array}{l}R_{3} \text { memperoleh palet dari buffer } 1 \text { dan } \\
\text { mengisi } M_{3}\end{array}$ \\
\hline$p_{17}$ & $\begin{array}{l}\text { Pengerjaan dengan mesin } M_{3} \text { bagian } \\
\text { bahan } F\end{array}$ \\
\hline$p_{18}$ & $\begin{array}{l}R_{2} \text { membongkar } M_{3} \text { dan meletakkan palet } \\
\text { pada AGV } 1\end{array}$ \\
\hline$p_{19}$ & $\begin{array}{l}\text { AGV } 1 \text { menyelesaikan bagian } F \text { ke exit } 1 \\
\text { dan melepaskan palet ke entri } 1\end{array}$ \\
\hline$p_{20}$ & $\begin{array}{l}\text { Bahan baku tipe } G \text { tersedia, Masing- } \\
\text { masing palet siap }\end{array}$ \\
\hline$p_{21}$ & $\begin{array}{l}R_{1} \text { memperoleh palet dari entri } 2 \text { dan } \\
\text { mengisi } M_{4}\end{array}$ \\
\hline$p_{22}$ & $\begin{array}{l}\text { Pengerjaan dengan mesin } M_{4} \text { bagian } \\
\text { bahan } G\end{array}$ \\
\hline$p_{23}$ & $\begin{array}{l}R_{4} \text { membongkar } M_{4} \text { dan menempatkan } \\
\text { bagian } G \text { pada } \text { buffer } 1\end{array}$ \\
\hline$p_{24}$ & Buffer 2 menyimpan bagian $G$ \\
\hline$p_{25}$ & $\begin{array}{l}R_{4} \text { memperoleh palet dari buffer } 2 \text { dan } \\
\text { mengisi } M_{5}\end{array}$ \\
\hline$p_{26}$ & $\begin{array}{l}\text { Pengerjaan dengan mesin } M_{5} \text { bagian } \\
\text { bahan } G\end{array}$ \\
\hline$p_{27}$ & $\begin{array}{l}R_{2} \text { membongkar } M_{5} \text { dan meletakkan palet } \\
\text { pada AGV } 2\end{array}$ \\
\hline$p_{28}$ & $\begin{array}{l}\text { AGV } 2 \text { menyelesaikan bagian } G \text { ke exit } \\
2 \text { dan melepaskan palet ke entri } 2\end{array}$ \\
\hline
\end{tabular}

Penambahan Non-Shared Resource: Lima mesin dan dua AGV digunakan dengan proses operasi tunggal, sehingga merupakan resource non-shared dalam sistem. akan ditambahkan place resource pada Petri net. Semua penambahan place resource ditunjukkan pada Gambar 5. Penambahan place baru merupakan milik himpunan place resource tetap.

$$
P_{B}=\left\{p_{12}^{\prime}, p_{13}^{\prime}, p_{17}^{\prime}, p_{19}^{\prime}, p_{22}^{\prime}, p_{26}^{\prime}, p_{28}^{\prime}\right\}
$$

Penjelasan atas place- $B$ dijelaskan pada Tabel 3.

Penambahan place buffer: Sistem ini terdiri dari dua buffer sederhana. Dua place-B dapat diartikan sebagai, $p^{\prime}{ }_{15}$ merupakan slot kosong dalam buffer 1 tersedia jika terdapat token di dalamnya dan $p_{24}^{\prime}$ merupakan slot kosong dalam buffer 2 yang juga tersedia jika terdapat token di dalamnya. Khususnya, $p^{\prime}{ }_{15}, p_{15}$ dan dua transisinya memenuhi kondisi pertama pada teorema yaitu 
$Z$ ' bounded (safe) jika $Z$ bounded (safe), konstruksi ini menghasilkan modul buffer yang menjaga sifat net sehingga boundedness, liveness, dan reversibility. Argumen yang sama dapat diterapkan untuk $p_{24}^{\prime}$ dan kedua transisinya. Ini jelas bahwa $m_{0}\left(p_{15}^{\prime}\right)=b_{1}$ dan $m_{0}\left(p_{16}^{\prime}\right)=b_{2}$.

Tabel 3. Label place untukm Petri net setelah penambahan non-shared resource

\begin{tabular}{|c|l|}
\hline Place & Interpretasi \\
\hline$p_{12}^{\prime}$ & $M_{1}$ siap \\
\hline$p_{13}^{\prime}$ & $M_{2}$ siap \\
\hline$p_{17}^{\prime}$ & $M_{3}$ siap \\
\hline$p_{19}^{\prime}$ & AGV 1 siap \\
\hline$p_{22}^{\prime}$ & $M_{4}$ siap \\
\hline$p_{26}^{\prime}$ & $M_{5}$ siap \\
\hline$p_{28}^{\prime}$ & AGV 2 siap \\
\hline
\end{tabular}

Penambahan shared resource untuk membentuk GPME: dengan mempertimbangkan robot $R_{2}$ yang berbagi dengan dua mesin $M_{3}$ dan $M_{5}$. Setelah $p_{2}$ dan arcnya ditambahkan ditambahkan seperti terlihat pada Gambar 5, nyata bahwa $\left(p_{2},\left(t_{9}, t_{10}\right),\left(t_{27} t_{28}\right)\right)$ adalah PME-2. Oleh sebab itu, net bounded, live, dan reversible. Selanjutnya dengan mempertimbangkan robot $R_{l}$ berbagi dengan $M_{1}, M_{2}$ dan $M_{4}$. Saat $M_{1}$ dan $M_{2}$ berbagi dengan entri, setelah $R_{l}$

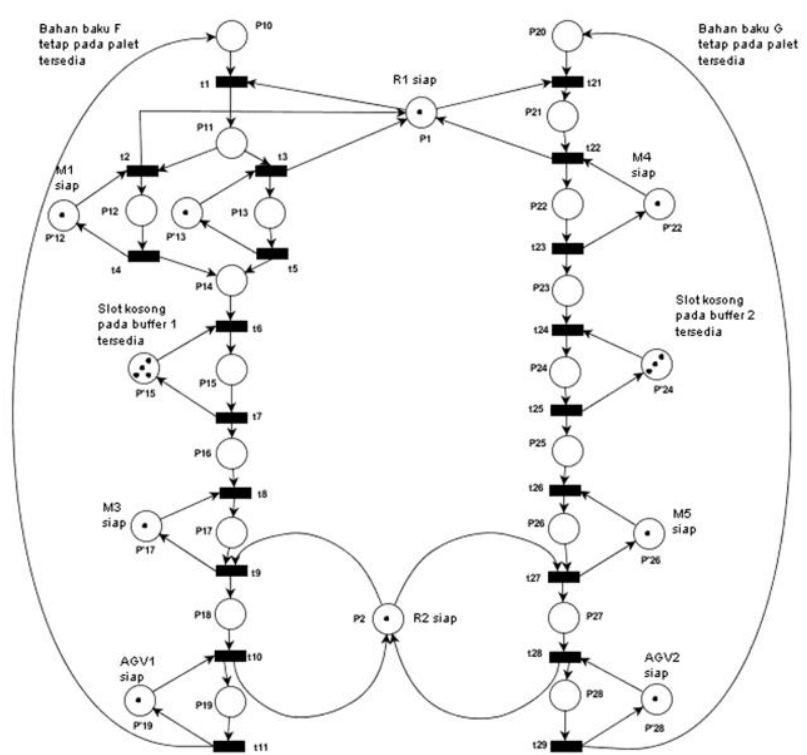

Gambar 5. Petri net setelah penambahan Robot $R_{l}$ dan $R_{2}$ memperoleh bahan baku $F$

Selanjutnya dapat mengisi $M_{1}$ atau $M_{2}$ saat keduanya idle. Share resource ini dimodelkan dalam Gambar 5. menggunakan place- $B p_{1}$. Hal ini juga memudahkan untuk memverifikasi bahwa $\left(p_{1},\left\{\left(t_{1},\left\{t_{2}, t_{3}\right\}\right),\left(t_{21} t_{22}\right)\right)\right.$ membentuk GPME. Oleh sebab itu teori menjamin boundedness, liveness, dan reversibility pada net dalam Gambar 5. selama token berada pada place-C. Dua place$B, p_{1}$ dan $p_{2}$, masing-masingnya berisi satu token, dengan keterangan $p_{1}: R_{1}$ siap dan $p_{2}: R_{2}$ siap.
Penambahan shared resource untuk membentuk GSME: bagian yang paling sulit adalah melakukan pencocokan dengan barisan shared resource. Sistem ini menyediakan dua macam resource, robot $R_{3}$ dan $R_{4}$. Sebagai contoh, $R_{4}$ pertama dibutuhkan untuk membongkar $M_{4}$, dan kemudian mungkin membongkar $M_{4}$ lagi atau $M_{5}$. membongkar $M_{4}$ dan $M_{5}$ merupakan dua barisan proses yang saling terkait. Selanjutnya hasil akhir desain Petri net digambarkan pada Gambar 6. Proses pemodelan dapat dibagi atas beberapa tahapan. Pertama, analisa robot $R_{3}$. Saat hanya $\operatorname{arc}\left(p_{3}, t_{4}\right),\left(p_{3}, t_{5}\right)$ dan $\left(t_{6}, p_{3}\right)$ ditambahkan pada net, maka GPME-1 terbentuk yaitu, $\left(p_{3},\left\{\left(\left\{t_{4}, t_{5}\right\}, t_{6}\right)\right\}\right)$. Saat $\operatorname{arc}\left(p_{3}, t_{7}\right)$ dan $\left(t_{8}, p_{3}\right)$ ditambahkan, maka struktur $\left(p_{3},\left\{\left(\left\{t_{4}, t_{5}\right\}, t_{6}\right)\right\} \cup\right.$ $\left.\left\{\left(t_{7}, t_{8}\right)\right\}\right)$ dapat diverifikasi sebagai GSME untuk sistem.

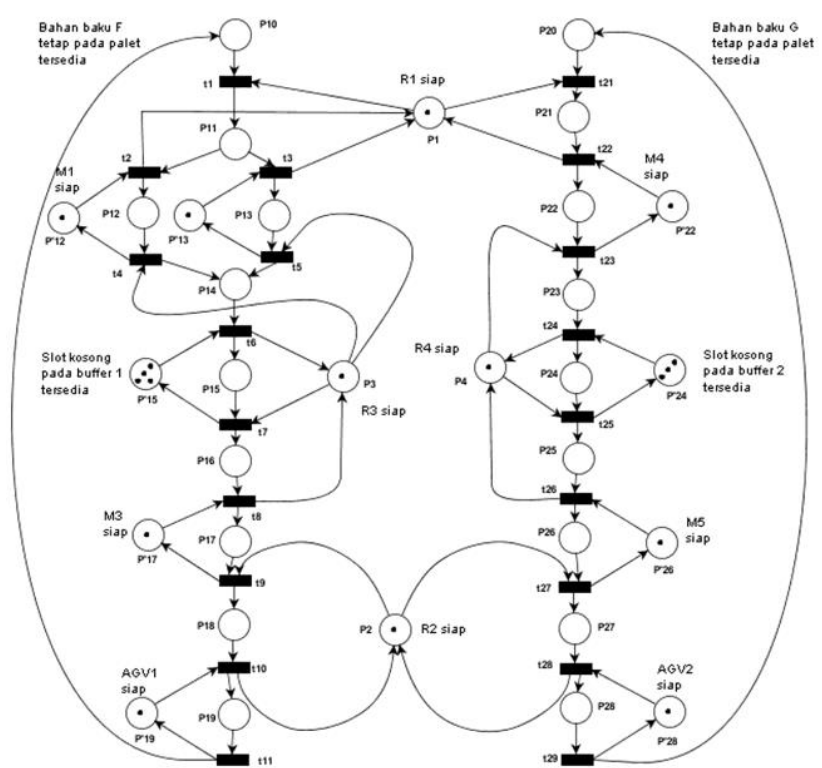

Gambar 6. Model akhir Petri net untuk AMS

Selanjutnya analisis kapasitas token, $\alpha, \beta$, dan $\gamma$ adalah sebagai berikut:

$$
\begin{gathered}
C^{1}=C\left(t_{6}, t_{7}\right)=b_{1} . \\
\alpha\left(p_{10}, t_{4}\right)=\alpha\left(p_{10}, t_{5}\right)=1, \alpha\left(p_{20}, t_{4}\right)=\alpha\left(p_{20}, t_{5}\right)=0 ; \\
\alpha\left(p_{10}\right)=1, \alpha\left(p_{20}\right)=0 . \\
\beta\left(p_{10}, t_{4}\right)=\beta\left(p_{10}, t_{5}\right)=1, \beta\left(p_{20}, t_{4}\right)=\beta\left(p_{20}, t_{5}\right)=0 ; \\
\beta\left(p_{10}\right)=1, \beta\left(p_{20}\right)=0 ; \\
\gamma\left(p_{10}, t_{4}\right)=\gamma\left(p_{10}, t_{5}\right)=m_{0}\left(p_{10}\right) .
\end{gathered}
$$

Sedemikian sehingga, dengan menggunakan teorema untuk GSME, inisial penandaan yang mungkin adalah:

$$
1 \leq m_{0}\left(p_{10}\right) \leq b_{1},
$$

dan

$$
1 \leq m_{0}\left(p_{20}\right)
$$

yang diperlukan untuk liveness dan reversibility. Kedua, analisa robot $R_{4}$. Struktur $\left.\left(p_{4},\left\{t_{23}, t_{24}\right)\right\} \cup\left\{\left(t_{25}, t_{26}\right)\right\}\right)$ dapat diverifikasi sebagai SME. Kapasitas token, $\alpha, \beta$, dan $\gamma$ dapat dihitung sebagai berikut:

$$
\begin{gathered}
C^{1}=C\left(t_{24}, t_{25}\right)=b_{2} . \\
\alpha\left(p_{10}\right)=0, \alpha\left(p_{20}\right)=1 \\
\beta\left(p_{10}\right)=0, \beta\left(p_{20}\right)=1
\end{gathered}
$$

dan

demikian sehingga

$$
\gamma\left(p_{20}, t_{23}\right)=m_{0}\left(p_{20}\right)
$$

$$
\gamma\left(t_{23}\right)=\infty
$$


Dengan menggunakan teorema untuk SME, diperoleh:

$$
1 \leq m_{0}\left(p_{10}\right)
$$

Sedemikian sehingga, dengan tujuan untuk menjamin sifat kwalitatif yang diharapkan pada net seperti Gambar 6 , inisial penandaan harus memenuhi:

dan

$$
1 \leq m_{0}\left(p_{10}\right) \leq b_{1}
$$

$$
1 \leq m_{0}\left(p_{20}\right) \leq b_{2}
$$

Dengan inisial penandaan yang telah diperoleh dan struktur Petri net seperti yang ditunjukkan pada Gambar 6, maka Petri net bounded, live, dan reversible. Himpunan place operasi, himpunan place fixed resource, dan himpunan variabel resource dapat ditulis sebagai berikut:

dan

$$
\begin{aligned}
P_{A}=\left\{p_{1 i}, 1 \leq i \leq 9\right\} \cup\left\{p_{2 i}, 1 \leq i \leq 8\right\} \\
P_{B}=\left\{p_{1}, p_{2}, p_{3}, p_{4}, p_{12}^{\prime}, p_{13}^{\prime}, p_{15}^{\prime},\right. \\
\left.p_{17}^{\prime}, p_{19}^{\prime}, p_{22}^{\prime}, p_{24}^{\prime}, p_{26}^{\prime}, p_{28}^{\prime}\right\}
\end{aligned}
$$

$P_{C}=\left\{p_{10}, p_{20}\right\}$
Sedangkan dengan tujuan untuk mengurangi kemungkinan terjadinya pada lingkungan operasional, dipilih:

dan

$$
m_{0}\left(p_{10}\right)=b_{1}
$$

$$
m_{0}\left(p_{20}\right)=b_{2}
$$

\section{KESIMPULAN}

Kesimpulan yang dapat diambil adalah dengan menggunakan metode hybrid, Petri net untuk sistem manufaktur dapat disintesis satu per satu, sehingga menghasilkan Petri net bounded, live dan reversible dengan 32 place dan 20 transisi.

\section{DAFTAR PUSTAKA}

Adzkiya, D. 2008, Membangun Petri Net Lampu Lalu Lintas dan Simulasinya,Tesis Magister, Institut Teknologi Sepuluh Nopember, Surabaya.

David, R. dan Alla, H. 2005, Discrete, Continuous, and Hybrid Petri Nets, Springer-Verlag Berlin Heidelberg, New York.

Murata, T. 1989, Petri Net: Properties, Analysis, and Applications, Proceedings of The IEEE, Eds: Department of Electrical Engineering and Computer Science, University of Illionis, Chicago, Vol. 77, No. 4, hal. 541-580.

Zhou, M. dan DiCesare, F. 1993. Petri Net Synthesis for Discrete Event Control of Manufacturing Systems, Kluwer Academic Publishers, Massachusetts. 